Diagnostic Microbiology and Infectious Disease 37 (2000) 271-273

Case reports
DIAGNOSTIC

MICROBIOLOGY

AND INFECTIOUS

DISEASE

www.elsevier.com/locate/diagmicrobio

\title{
Spontaneous bacterial empyema caused by Aeromonas veronii biotype sobria
}

\author{
Jann-Tay Wang, Chi-Tai Fang, Po-Ren Hsueh, Shan-Chwen Chang*, Kwen-Tay Luh
}

Departments of Internal Medicine and Laboratory Medicine, National Taiwan University Hospital, Taipei, Taiwan

\begin{abstract}
Spontaneous bacterial empyema is a complication of hepatic hydrothorax in cirrhotic patients. The pathogen, clinical course and treatment strategy are different to the empyema secondary to pneumonia. A 54-year-old man, who was a cirrhotic patient with hepatic hydrothorax, was admitted to National Taiwan University Hospital for fever, dyspnea and right side pleuritic pain. The image study revealed massive right pleural effusion and no evidence of pneumonia. The culture of pleural effusion yielded Aeromonas veronii biotype sobria. The diagnosis of spontaneous bacterial empyema caused by Aeromonas veronii biotype sobria was established. To our best knowledge, Aeromonas veronii biotype sobria had never been reported in English literature as the causative pathogen of spontaneous bacterial empyema. (C) 2000 Elsevier Science Inc. All rights reserved.
\end{abstract}

\section{Introduction}

Spontaneous bacterial empyema may complicate the course of hepatic hydrothorax, just as spontaneous bacterial peritonitis (SBP) complicates the course of ascites, in patients with decompensated liver cirrhosis (Flaum, 1976; Xiol et al., 1996; Xiol et al., 1990; Hsieh et al., 1998; Isobe et al., 1994). Hepatic hydrothorax occurs in $3 \%$ of cirrhotic patients (Chu et al., 1996). About $13 \%$ of patients with hepatic hydrothorax develop spontaneous bacterial empyema, often in the absence of concomitant SBP or ascites (Xiol et al., 1996). Patients with spontaneous bacterial empyema have a case fatality rate as high as $20 \%$, and prompt appropriate antibiotic treatment is required to minimize the morbidity and mortality (Xiol et al., 1996). Known microbial pathogens associated with spontaneous bacterial empyema include Escherichia coli, Streptococcus spp., Enterococcus spp., Klebsiella pneumoniae, Morganella morganii, Clostridium perfringens, Aeromonas hydrophila, and Pseudomonas stutzeri (Flaum, 1976; Xiol et al., 1996; Xiol et al., 1990; Hsieh et al., 1998; Isobe et al., 1994). Aeromonas veronii biotype sobria has not been reported as a causative pathogen of spontaneous bacterial empyema. We now present a patient with spontaneous bacterial empyema caused by $A$. veronii biotype sobria. He was successfully

\footnotetext{
* Corresponding author. Tel.: +1-886-2-23123456 Ext 5045; fax: +1886-2- 23971412.

E-mail address: sc4030@ha.mc.ntu.edu.tw (S.C. Chang).
}

treated with i.v. cefotaxime and pigtail drainage, without the insertion of a chest tube.

\section{Case report}

A 54-year-old man presented with progressive dyspnea, fever, and right side pleuritic pain for three days. He had a history of hepatitis B-related liver cirrhosis for three years. Four months prior to admission, moderate amount right pleural effusion was noted on chest roentgenography (CXR). Pleural fluid analysis at that time revealed a transudate and hepatic hydrothorax was diagnosed. At admission, his body temperature was $37.8^{\circ} \mathrm{C}$, pulse rate 96 beats/ $\mathrm{min}$, respiratory rate $24 / \mathrm{min}$, blood pressure $114 / 70 \mathrm{mmHg}$. The sclera was icteric and conjunctiva was pale. Auscultation of chest revealed decreased breath sound over the right lower lung field. The abdomen was soft and distended. Percussion of abdomen revealed increased splenic dullness. Shifting dullness was also detected. There was a massive right pleural effusion, increased amount, on CXR without evidence of pneumonia. Pleural fluid study yielded an exudate with turbid appearance, white cell count of $14900 / \mathrm{mm}^{3}$ with $80 \%$ of neutrophil, lactate dehydrogenase (LDH) 392 $\mathrm{U} / \mathrm{dL}$ and protein $1.6 \mathrm{~g} / \mathrm{dL}$. The complete peripheral blood cells counts showed a white cell count of $3540 / \mathrm{mm}^{3}$ with $76.6 \%$ of neutrophil. Serum biochemistry results were albumin $2.6 \mathrm{~g} / \mathrm{dL}$, globulin $3.9 \mathrm{~g} / \mathrm{dL}, \mathrm{LDH} 317 \mathrm{U} / \mathrm{dL}$ and glucose $95 \mathrm{mg} / \mathrm{dL}$. Ascitic fluid analysis at the same time 
revealed a transudate with white cell count of $20 / \mathrm{mm}^{3}$ protein $10 \mathrm{mg} / \mathrm{dL}$ and negative bacterial culture. Under the impression of spontaneous bacterial empyema, he was put on $4 \mathrm{~g}$ i.v. cefotaxime per day. A pigtail catheter was inserted into the right pleural cavity for drainage of the massive pleural effusion to relieve his dyspnea. The culture of pleural fluid was done by inoculation of $10 \mathrm{~mL}$ pleural effusion into the blood culture bottles and incubated at $35^{\circ} \mathrm{C}$. An oxidase-positive Gram-negative bacillus grew 3 days later, which was subsequently identified as $A$. veronii biotype sobria by resistance to O129 (10 $\mu \mathrm{g}$ disk), positive arginine dihydrolase and lysine decarboxylase test, negative ornithine decarboxylase test, positive Voges-Prokauer test, negative esculin hydrolysis test, positive results of acid from sucrose and mannitol, and negative result of acid from arabinose. His fever subsided 3 days after admission. The $A$. veronii biotype sobria isolate was susceptible to cefotaxime, aztreonam, ciprofloxacin, and imipenem-cilastatin but resistant to amoxicillin-clauvulanate by the disk susceptibility test. Cefotaxime was continued for 13 days and then changed to oral cefixime $1 \mathrm{gm}$ bid. On the follow-up CXR, taken 12 days after admission, the right pleural effusion decreased but did not totally subside. The pleural fluid turned back to transudate 17 days after admission, with a white cell count of $10 / \mathrm{mm}^{3}$, glucose $126 \mathrm{mg} / \mathrm{dL}$, total protein $0.7 \mathrm{~g} / \mathrm{dL}$ (serum total protein, $7.0 \mathrm{~g} / \mathrm{dL}$ ), LDH $170 \mathrm{U} / \mathrm{dL}$ (serum, $378 \mathrm{U} / \mathrm{dL}$ ) and negative bacterial culture. The pigtail catheter was removed and he was discharged in stable condition.

\section{Discussion}

Xiol et al. proposed a diagnostic criteria for spontaneous bacterial empyema (Xiol et al., 1996): (1) clinical evidence of fever or shock; (2) positive pleural fluid culture or, if negative, a pleural fluid neutrophil count greater than 500 cells $/ \mathrm{mm}^{3}$; (3) no evidence of pneumonia on chest radiology; and (4) preexisted hepatic hydrothorax. When all the above criteria were fulfilled, the diagnosis of spontaneous bacterial empyema was established. Our patient fulfilled all the criteria, and his pleural effusion culture grew $A$. veronii biotype sobria.

Aeromonads are ubiquitous inhabitants of fresh and brackish water (Ko et al., 1995). Although they were believed to be opportunistic pathogens of low virulence, Aeromonads can cause invasive infections, especially in patients with hepatobiliary diseases, malignancy and diabetes mellitus (Ko et al., 1995; Janda et al., 1998). The portal of entry is believed to be gastrointestinal tract, transmitted through contaminated water or food in most cases (Dryden et al., 1989). A. hydrophila, A veronii biotype sobria, A. caviae, $A$. veronii biotype veronii and $A$. jandaei are the five clinically important species. Many clinicians still use the name of A. sobria as a synonym for the now correct designation A. veronii biotype sobria (Altwegg et al., 1999). To identify the Aeromonads of clinical significance to the species level is somewhat difficult (Janda et al., 1998). A series of biochemical reactions, including lysine decarboxylase test, ornithine decarboxylase test, arginine dihydrolase test, VogesProskauer test, Esculin hydrolysis test, acid from sucrose, acid from arabinose, and acid from mannitol, can separate these five species (Janda et al., 1998; Altwegg et al., 1999). Our isolate was identified to be $A$. veronii biotype sobria using these biochemical tests. A. veronii biotype sobria has been reported as a pathogen of bacteremia (Ko et al., 1995; Hsueh et al., 1998), SBP in patients with liver cirrhosis (Ko et al., 1995; Dryden et al., 1989; Garcia et al., 1992), cellulitis related to the use of leeches (Fenollar et al., 1999), colitis and gastroenteritis (Deutsch et al., 1997; Deodhar et al., 1991; Gelbart et al., 1985), pneumonia in near-drowning people (Ender et al., 1996), wound infection (Newton et al., 1993), and cholera-like illness (Champsaur et al., 1982). Our report adds to the literature that A.veronii biotype sobria can also cause spontaneous bacterial empyema.

Unlike other Aeromonas spp., A. veronii biotype sobria is uniformly resistant to amoxicillin-clauvulanate (Burgos et al., 1990). Third-generation cephalosporins or fluoroquinolones are the agents of choice (Garcia et al., 1992; Burgos et al., 1990). In the present case, $A$. veronii biotype sobria was successfully treated with cefotaxime.

The management of spontaneous bacterial empyema is different from that of empyema secondary to pneumonia (Xiol et al., 1990). Empiric antibiotic regimens should cover enteric Gram-negative bacilli, including Aeromonads (Xiol et al., 1996; Xiol et al., 1990). Furthermore, chest tube insertion is not necessary for spontaneous bacterial empyema (Xiol et al., 1996; Xiol et al., 1990; Hsieh et al., 1998). Successful treatment has been reported using antibiotic therapy and pigtail drainage, or even antibiotic therapy alone (Xiol et al., 1996; Xiol et al., 1990; Hsieh et al., 1998).

In summary, we report a case of spontaneous bacterial empyema caused by $A$. veronii biotype sobria in a cirrhotic patient with pre-existing hepatic hydrothorax. Treatment using i.v. cefotaxime and pigtail drainage proved successful.

\section{References}

Altwegg, M. (1999). Aeromonas and Plesiomonas. In P. R. Murray, E. J. Baron, M. A. Pfaller, F. C. Tenover, R. H. Yolkens (Eds.), Manual of clinical microbiology. (7th ed.) Washington, DC: American Society for Microbiology: pp 507-16.

Burgos, A., Quindos, G., Martinez, R., Rojo, P., \& Cisterna, R. (1990). In vitro susceptibility of Aeromonas caviae, Aeromonas hydrophila, and Aeromonas sobria to fifteen antibacterial agents. Eur J Clin Microbiol Infect Dis, 9, 413-7.

Champsaur, H., Adremont, A., Mathieu, D., Rottman, E., \& Auzepy, D. (1982). Cholera-like illness due to Aeromonas sobria. J Infect Dis, 145, 248-54.

Chu, C. H., Kao, C. R., Shin, S. C., Chou, S. Y., Wang, H. Y., Lin, S. C., \& Shin, B. F. (1996). Hepatic hydrothorax: clinical experience and analysis. Gastroenterol J Taiwan, 13, 171-7.

Deodhar, L. P., Saraswathi, K., \& Varudkar, A. (1991). Aeromonas spp. and their association with human diarrheal disease. J Clin Microbiol, $29,853-6$. 
Deutsch, S. F., \& Wedzina, W. (1997). Aeromonas sobria associated left-sided segmental colitis. Am J Gastroenterol, 92, 2104-6.

Dryden, M., \& Munro, R. (1989). Aeromonas septicemia: relationship of species and clinical features. Pathology, 21, 111-4.

Ender, P. T., Dolan, M. J., Dolan, D., Farmer, J. C., \& Melcher, G. P. (1996). Near-drowning associated Aeromonas pneumonia. J Emerg Med, 14, 737-41.

Fenollar, F., Fournier, P. E., \& Legre, R. (1999). Unusual case of Aeromonas sobria cellulitis associated with the use of leeches. Eur J Clin Microbiol Infect Dis, 18, 72-3.

Flaum, M. A. (1976). Spontaneous bacterial empyema in cirrhosis. Gastroenterology 70, 416-7.

Garcia, M., Sanroman, A. L., Gisbert, J. P., Marin de, A. C., \& Moreira, V. F. (1992). Aeromonas sobria spontaneous bacterial peritonitis. Am J Gastroenterol 87, 1890-1.

Gelbart, S. M., Prabhudesai, M., \& Magee, S. M. (1985). A case report: Aeromonas sobria gastroenteritis in an adult. Am J Clin Pathol, 83, 389-91.

Hsieh, Y. H., Chan, C. C., Wang, S. S., Chiang, H. H., Chou, D. Y., Chang, F. Y., \& Lee, S. D. (1998). Recurrent spontaneous bacterial empyema in cirrhosis: a case report. Chin Med J (Taipei), 61, 421-6.
Hsueh, P. R., Teng, L. J., Lee, L. N., Yang, P. C., Chen, Y. C., Ho, S. W., \& Luh, K. T. (1998). Indwelling device-related and recurrent infections due to Aeromonas species. Clin Infect Dis, 26, 651-8.

Isobe, H., Motomura, K., Kotou, K., Sakai, H., Satoh, M., \& Nawata, H. (1994). Spontaneous bacterial empyema and peritonitis caused by Morganella morganii. J Clin Gastroenterol, 18, 87-8.

Janda, J. M., \& Abbott, S. L. (1998). Evolving concepts regarding the genus Aeromonas: an expanding panorama of species, disease presentations, and unanswered questions. Clin Infect Dis, 27, $332-44$.

Ko, W. C., \& Chuang, Y. C. (1995). Aeromonas bacteremia: review of 59 episodes. Clin Infect Dis, 20, 1298-304.

Newton, J. A. Jr., \& Kennedy, C. A. (1993). Wound infection due to Aeromonas sobria. Clin Infect Dis, 17, 1082-3.

Xiol, X., Castellote, J., Baliellas, C., Ariza, J., Gimenez, R. A., Guardiola, J., \& Casais, L. (1990). Spontaneous bacterial empyema in cirrhotic patients: analysis of eleven cases. Hepatology, 11, 365-70.

Xiol, X., Castellvi, J. M., Guardiola, J., Sese, E., Castellote, J., Perello, A., Cervantes, X., \& Iborra, M. J. (1996). Spontaneous bacterial empyema in cirrhotic patients: a prospective study. Hepatology, 23, 719-23. 